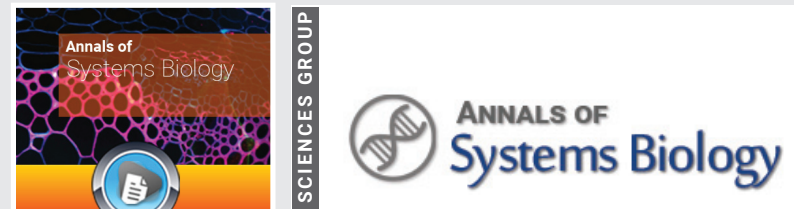

Review Article

\title{
Defensive strategies of ROS
} in Programmed Cell Death associated with hypertensive response in plant pathogenesis

\author{
Nivedita Dey ${ }^{3}$, Utpal Krishna Roy ${ }^{1}$, Manashi Aditya ${ }^{2}$ and \\ Soumen Bhattacharje ${ }^{3 *}$ \\ 1Department of Botany, Rajsahi University, Rajsahi, Bangladesh \\ ${ }^{2}$ Post Graduate Department of Botany, Hooghly Mohsin College, Chinsurah-712101, West Bengal, India \\ ${ }^{3}$ Plant Physiology \& Biochemistry Research laboratory, UGC Centre for Advanced Study, Department of \\ Botany, The University of Burdwan, Burdwan, West Bengal, India
}

Received: 24 February, 2020

Accepted: 14 March, 2020

Published: 16 March, 2020

*Corresponding author: Soumen Bhattacharjee, Plant Physiology \& Biochemistry Research laboratory, UGC Centre for Advanced Study, Department of Botany, The University of Burdwan, Burdwan, West Bengal, India, Tel: 09433778493; E-mail: soumen1995@yahoo.com; sbhattacharjee@bot.buruniv.ac.in

Keywords: Biotic stress; Reactive oxygen species; Programmed cell death; Necrosis; Pathogenesis

https://www.peertechz.com

Check for updates

\begin{abstract}
One of the important initial events upon recognition of a plant pathogen is the changes in the redox status of the infected cells due to the accumulation of Reactive Oxygen Species (ROS). Though plants have evolved an array of defensive strategies to resist stresses, including those from attack by pathogens, but the changed redox cue of the infected cells are often exploited by the plant for specific purpose as well. It is becoming evident gradually that ROS or the redox cue, which are generated during pathogen attack are recognized by plant as a signaling agent for triggering responses. The necrosis of infected tissue caused by ROS during pathogen infection increases host susceptibility to necrotrophic pathogen, but exhibit resistance to biotrophic pathogen. Evidences further support the view that ROS serve as a 'second messenger' in a systemic signaling network in plant defence leading to the expression of specific genes that trigger hypersensitive Response (HR). Avirulent pathogens often induce a biphasic ROS accumulation with a weak transient first phase, followed by a more intense continuous phase. A range of enzyme systems like respiratory burst oxidase homolog (Rboh or NADPH oxidase), Superoxide Dismutase (SOD) have been implicated in ROS turnover following pathogen recognition. In this review we provide the relevant findings of signaling role of ROS in plant defence responses. Special attention is given to the role of ROS in Programmed Cell Death (PCD) associated with HR during pathogenesis in plants.
\end{abstract}

\section{Introduction}

Biotic stresses caused by pathogenic infection spur the generation of ROS in plants through distinct pathways involving specific ROS-producing enzymatic systems that results in accumulation of cellular or intercellular prooxidants [1]. Biotrophic pathogen prefer living, while necrotrophic one prefer dead cells for nutritional purposes. Therefore, tissue necrosis caused by ROS during pathogen infection increases host susceptibility to necrotrophic but resistance to biotrophic pathogen.

Many pathogen infections to plant induce a radical burst. It is one of the earliest events in the plant defence response [1]. ROS play pivotal role in survival and death of the plants. Many regulators are not only involved in growth and development but are also involved in limiting pathogen ingression, induction of apoptosis and signal transduction of several defence processes, thereby playing pivotal role in both cell survival and death [2]. Pathogen-induced burst of ROS production, particularly , Hydrogen peroxide $\left(\mathrm{H}_{2} \mathrm{O}_{2}\right)$, at the plant cell surface drives rapid peroxidase-mediated oxidative cross-linking of structural proteins of cell wall, thereby strengthening this physical barrier against pathogen ingress [3]. After pathogen infection a battery of enzymes including Rboh or NADPH oxidase, peroxidases, SOD, oxalates oxidases, Lipoxygenases (LOX), quinone reductase-b and amine oxidases are up-regulated and involve in ROS generation and transition [4]. The burst of ROS production has been implicated in diverse physiological processes including resistance to biotic and abiotic stress [5]. Deciphering the physiology and implication of oxidative burst associated with stress elicitation in plants has been the subject 
of investigation for quite a long time. The necessity for ROS appears to be diverse for resistance to different pathogens $[6,7]$. ROS seems to play a critical role as signalling intermediates during the defence responses to bacterial pathogens [8]. In non-stressed plant tissues both enzymatic and non-enzymatic antioxidants are able to maintain redox homeostasis by neutralizing the harmful effects of ROS. In fact, the greater kinetics of ROS generation and poor antioxidant efficiency in severe biotic sstresses accelerates cellular necrosis and PCD [9].

\section{Implication of oxidative stress in plant-pathogen inte- raction}

ROS has been found to be closely integrated with the damage of the tissue observed during pathogenic infection. Previous studies exhibited that ROS are produced by plant cells on invasion of the pathogens $[10,11]$. The change in redox status of the infected tissue due to accelerated generation of ROS following the infection by pathogenic organism is one of the fastest plant responses to infection. As a result, $\mathrm{H}_{2} \mathrm{O}_{2}$ is detected in significantly greater amount within 2-3minutes following the addition of elicitor prepared from walls of the pathogen Verticillium dahliae to soybean cell cultures. The occurrence of fungal cell wall degrading enzymes, elicit a swift oxidative burst in host cells as well. In fact, the oxidative burst in infected plant cells is found to happen as almost a generalized phenomenon in response to pathogen or herbivore attack [12].

Fascinatingly, with the bacterial pathogens, two oxidative bursts are detected:

(i) Initial ROS burst, that takes place within half an hour of inoculation which may persist subsequently for another half an hour.

(ii) Delayed ROS burst, 4-6 hours post-inoculation that persist for several hours [13]

The first phase of oxidative burst probably constitutes a general plant response due to pathogen attack. It occurs in all types of pathogen i.e. avirulent, virulent or saprophytic. However, the second phase of oxidative burst is only restricted to incompatible interactions of plant with avirulent pathogen. When compared, between the oxidative bursts of two phases, the second phase of oxidative burst most likely plays the most important physiological role in the outcome of attack i.e. by suppressing the bacterial growth through induction of $\mathrm{HR}$ mechanism [11].

\section{Role of oxidative burst in defence response during infection}

The oxidative burst or change in internal redox cue of the infected tissue has several functions in defence response against pathogens:

(i) Just after infection it provides ROS $\mathrm{H}_{2} \mathrm{O}_{2}$, necessary for establishing cross-linking between the cell wall proteins by a peroxidase-catalyzed reaction, impeding further pathogen ingress [11]. (ii) The elevated concentration of ROS induces a signaling mechanism thereby activating subset of inducible defence genes necessary for survival.

(iii) Once the endogenous concentration of ROS reaches a certain threshold value, cell wall activate PCD, which in turn has two major functions during pathogenesis -

a) Starving the biotrophic pathogens, that ultimately deprives them from having essential nutrients [1].

b) Following the breakdown of cell compartmentalization, toxic antimicrobial chemicals leak out of the vacuole further poisoning the pathogens.

c) Finally, the high local concentrations of ROS further destruct the microbial pathogen by oxidative damage.

\section{ROS in plant defence mechanism}

$\mathrm{H}_{2} \mathrm{O}_{2}$, being a strong oxidant, is an electron-accepting molecule for Phenol Oxidase (POX) dependent reactions. POXs are generally considered to be merely ROS-detoxifying enzymes. The degradation of $\mathrm{H}_{2} \mathrm{O}_{2}$ by the POX reaction is extremely dynamic especially in the presence of ROS-scavenging POX substrates such as polyphenols and flavonoids [14]. Studies have shown that the Salicylic Acid (SA)-induced extracellular POX-dependent transient bursts of ROS trigger an initiation of $\mathrm{Ca}^{2+}$ signaling [15]. Supplementation of tobacco cell culture with purified Horse radish peroxidase markedly enhanced the SA-induced and Aromatic Monoamines (AMA)-induced $\mathrm{Ca}^{2+}$ increments, suggesting peroxidase enhances Superoxide $\left(\mathrm{O}_{2}\right)$ generation and stimulates the $\mathrm{Ca}^{2+}$ influx [15]. Thus, the SAand AMA-induced extracellular redox signals are transduced into the intracellular $\mathrm{Ca}^{2+}$ signal, probably leading to activation of the defence mechanism [16].

The oxidant $\mathrm{H}_{2} \mathrm{O}_{2}$ is believed to participate two separate roles during pathogenesis. The first one involves the restriction of pathogen growth and the other, induction of the synthesis of phytoalexins and Pathogenesis Related (PR) proteins. Several works support the view that $\mathrm{H}_{2} \mathrm{O}_{2}$ is a putative signal for the induction of subset of defence genes during pathogenesis. In this regard, the expression of $\mathrm{H}_{2} \mathrm{O}_{2}$-induced enzymes in transgenics has provided a novel way to study the plant defence resistance. Expression of a gene encoding glucose oxidase in transgenic potato led to $\mathrm{H}_{2} \mathrm{O}_{2}$ accumulation and increased resistance to soft rot and potato late blight disease. Several author noticed $\mathrm{H}_{2} \mathrm{O}_{2}-$ mediated enhancement of expression of PR genes, antioxidant enzymes, phytoalexins $[17,18] . \mathrm{H}_{2} \mathrm{O}_{2}$ mediated enhancement in the accumulation of SA is also noticed [19]. Though, on certain situations, the plant POXs produces ROS, but there are instances of extracellularly secreted POX in the elicitor-treated plants as well [20], although responsible electron-donating substrates are obscure. Bolwell, et al. [21], has proposed a model for the $\mathrm{H}_{2} \mathrm{O}_{2}$-producing reaction catalysed by an elicitor-stimulated $\mathrm{p}^{\mathrm{H}}$-dependent cell-wall POX. In this hypothetical model, after the elicitors being recognized by putative membrane receptors, ion channels are found to be up-regulated, causing the movements of proton and other ions and changing the extracellular matrix to an alkaline $\mathrm{p}^{\mathrm{H}}$, eventually activating the

Citation: Dey N, Roy UK, Aditya M, Bhattacharjee S (2020) Defensive strategies of ROS in Programmed Cell Death associated with hypertensive response in plant pathogenesis. Ann Syst Biol 3(1): 001-009. DOI: https://dx.doi.org/10.17352/asb.000004 
POX. Since the entire episode solely depends on $\mathrm{p}^{\mathrm{H}}$ changes and involves no specific substrate, generation of ROS involving SA, AMAs and Chitooligosaccharides (COSs) necessitates alternative mechanism. It is now commonly accepted that in case of SA signaling ROS production is a prerequisite and it often recruits $\mathrm{Ca}^{2+}$ as second messenger $[22,23]$.

Plant Mitogen-Activated Protein Kinases (MAPKs) are uniting point in signaling module after perception of pathogens and elicitors. As evidence, it is found that ROS act upstream of the MAPK cascade during ROS-induced activation of MAPKs associated with pathogenesis. However, investigations on different plant-pathogen interactions showed that the secondary peak of the biphasic ROS burst in response to pathogen infection might be due to MAPK and $\mathrm{Ca}^{2+}$-dependent kinase pathways which may be a part of an amplification network upstream of Rboh genes. Mutant experiments with a gain-of-function mutant of tobacco MEK2 (a mitogenactivated protein kinase kinase 2), when expressed, found to up-regulate the downstream kinases and induces PCD, even in the absence of pathogen. The activation and expression of $M E K 2$ caused failure of membrane potential, electrolyte outflow and ROS generation in both the organelle chloroplasts and mitochondria, which was preceded by metabolic dysfunction of cell [24]. One more piece of corroboration of the role played by chloroplasts in the early signaling for the HR, came from studies on the Arabidopsis under the exposure to ozone, which shares a lot of characters in common with pathogeninduced HR, including biphasic oxidative burst. It was found that the early phase of ROS accumulation and redox changes was confined to the guard cell chloroplasts, followed by extracellular production of ROS in the plasma membrane of the same cells (through Rboh activity), which subsequently extend to adjacent tissues. Those findings suggest that chloroplasts are the initial source of ROS during the HR, resulting from shutdown of photosynthetic carbon reduction cycle (PCRC) of chloroplast stroma, and leading to over-reduction of the photosynthetic electron transport chain, ultimately generating $\mathrm{O}_{2}{ }^{-}$and other ROS. The ROS-linked signals are then one way or another corresponds to the plasma membrane for apoplastic oxidative burst and subsequently spread to adjacent cells. The function of lipid peroxides in propagating the signal from chloroplasts to other sources of ROS should be investigated at length for understanding the role of retrograde ROS signaling in pathogenesis.

\section{ROS signaling during plant defence mechanism}

The endogenous titer of ROS in plant cells per se at any point is determined by the relative rates of ROS generation and destruction within a given compartment. $\mathrm{H}_{2} \mathrm{O}_{2}$ being relatively most stable form of ROS may act as second messenger in several signaling circuits, since it could diffuse from the site of production and subsequently cause microburst of ROS formation. In incompatible plant-pathogen interactions, $\mathrm{H}_{2} \mathrm{O}_{2}$ has been implicated in the elicitation of variety of defence responses [11]. Among these the most significant is the induction of glutathione S-transferases (GSTs) and glutathione peroxidase (GPX). ROS, particularly $\mathrm{H}_{2} \mathrm{O}_{2}$ can influence the glutathione turnover by influencing the recycling of oxidised glutathione (GSSG) and reduced Glutathione (GSH), thereby have an impact on internal redox status of the cell (by changing thiol/disulphide exchange ratio) which ultimately can instigate redox signaling.

Apart from the oxidative burst, expression of several defencerelated genes is also up-regulated by harpin in Arabidopsis suspension cultures. Such genes include PAL (encoding phenyl alanine ammonia lyase), a key enzyme of phenyl propanoid metabolism and GST (encoding glutathione-S-transferase), necessary for detoxification of lipid hydroperoxides generated during oxidative stress. The expression of these defence-genes can be induced by $\mathrm{H}_{2} \mathrm{O}_{2}$ in a time and dose-dependent manner [25]. Experiments related to the characterization of catalase (CAT) as a SA-binding protein along with other relevant experiments suggest that $\mathrm{H}_{2} \mathrm{O}_{2}$ is downstream of SA-induced $\mathrm{PR}(P R-1)$ gene induction [26].

Several experiments demonstrated that $\mathrm{H}_{2} \mathrm{O}_{2}$ is a diffusible signal in the induction of plant defence genes, namely GST, GPX etc. A CAT trap, placed between soyabean cells inoculated with an avirulent pathogen and uninfected cells, blocked the diffusible signal that originated from infected cells necessary for defence-gene induction was observed [11]. Transgenic plants with elevated levels of $\mathrm{H}_{2} \mathrm{O}_{2}$ due to constitutive over production of glucose oxidase or repression of peroxisomal CAT were more resistant to pathogens, accumulated SA and expressed PR genes [27-29]. Accumulation of $\mathrm{H}_{2} \mathrm{O}_{2}$ in terms of CAT-deficient tobacco plants was sufficient to induce the production of defence proteins (GPX, PR-1), not only locally, but also systematically [29].

A general notion is that $\mathrm{H}_{2} \mathrm{O}_{2}$ is a diffusible molecule with half-life of only $1 \mathrm{~ms}$, which essentially excludes of it being mobile signal for the induction of defensive responses in systemic tissues. But the work of Alvarez, et al., (1998) [30], proposed that this problem of short half-life of $\mathrm{H}_{2} \mathrm{O}_{2}$ may be overcome by a relay of $\mathrm{H}_{2} \mathrm{O}_{2}$-generating micro bursts, including NADPH oxidase, as a mechanism for the reiteration of these micro bursts. Such an important model was projected based on the microscopic observation of lesions of HR that appear throughout the Arabidopsis plants upon infection with avirulent bacterial pathogens. This micro-HRs is correlated with achievement of resistance and expression of defence-genes (GST, PR-2) and at the same time could be blocked by the application of an inhibitor of NADPH oxidase, Diphenyleneiodonium (DPI). Moreover, application of glucose oxidase, a $\mathrm{H}_{2} \mathrm{O}_{2}$ generating system, was sufficient to induce these responses [30].

The ROS, $\mathrm{O}_{2} \cdot-$ or its subsequently resulting products are also capable of potentiating a signaling process, activating defence responses. Jabs, et al., (1996) [31] and Jabs (1999) [32] showed that in soybean phytoalexin synthesis in response to pathogens or some specific elicitors is inhibited by DPI and SOD, but not by CAT. In another study it is also shown that $\mathrm{O}_{2}^{--}$, but not $\mathrm{H}_{2} \mathrm{O}_{2}$, is essential to induce accumulation of $P R-1$ mRNA and lesion formation in $l s d 1$ mutant (lesion-stimulating disease 1 resistance response) of Arabidopsis [32,31]. Furthermore, 
it was also found that one of the members of tomato multigene family capable of encoding extensin is transcriptionally activated upon treatment with digitonin or xanthine oxidase, the $\mathrm{O}_{2}^{--}$generating compounds, but not with $\mathrm{H}_{2} \mathrm{O}_{2}$ [33]. Similarly, bacteria and yeast exhibited induction of distinct defence proteins in response to either $\mathrm{O}_{2}{ }^{-}$or $\mathrm{H}_{2} \mathrm{O}_{2}$, though a substantial overlap present between both the responses. So, all the previous works conclusively prove the fact that $\mathrm{O}_{2}{ }^{-}$can also act as signaling molecule independently of $\mathrm{H}_{2} \mathrm{O}_{2}$ in defence responses to implement its stress acclamatory function.

Pathogen-induced ROS are not only detrimental to plant but may also be considered as intermediary signaling component of a very complicated ROS signaling network. Modulated endogenous titre of ROS are perceived by different sensors, (thiol, non thiol and antioxidant based molecules). Although ROS receptors are not so well characterized, at present, plant cells sense ROS via at least four different mechanisms:

(i) Protein associated thiol based receptor

(ii) Heat shock factors capable of working as redoxsensitive transcription factors

(iii) ROS mediated modulation of phosphatases associated signaling

(iv)and antioxidant-coupled s sensing mechanisms [2].

The initial responses of plant cells during pathogenesis include changes in membrane trafficking, which often causes influx of $\mathrm{Ca}^{2+}$ and proton and efflux of $\mathrm{K}^{+}$and $\mathrm{Cl}^{-}$[34]. Fluxes of ions then bring about extracellular production of ROS catalysed by NADPH oxidase, that significantly in the signaling event as secondary messengers associated with HR and defence gene expression [1]. Divalent calcium has been shown to be extremely significant in PR signaling triggered by oxidative burst. The ROS, $\mathrm{H}_{2} \mathrm{O}_{2}$ found to trigger calcium influx-mediated change in stomatal conductance in Commelina communis and Arabidopsis thaliana [35]. Calcium channel blocker $\left(\mathrm{LaCl}_{3}\right)$ found to hold back bacterial elicitor-induced ROS production in tobacco, substantiating further the role of $\mathrm{Ca}^{2+}$ signaling [13]. Moreover, it is also observed that transient up-regulation of the gene-ATCNGC11/12, responsible for the synthesis of a cyclic nucleotide-gated ion channel protein in Nicotiana benthamiana gave rise to cellular senescence with characteristics of the HR. It was revealed that this gene could potentiate the role as a $\mathrm{Ca}^{2+}$ conducting channel and those calcium ions were significant for the observed cell death.

Two diverse models implicating the role of calcium associated with the redox regulation during pathogenesis have been proposed. One model (Figure 1) put forward the fact that an elicitor (pathogen) interacts with a G-protein coupled receptor which leads to activation of Phospholipases $\mathrm{C} / \mathrm{A}$, ultimately inducing $\mathrm{IP}_{3}$ mediated $\mathrm{Ca}^{2+}$ influx responsible for activating a $\mathrm{Ca}^{2+}$ dependent protein kinase and ultimately NADPH oxidase [36]. Another model of calcium associated with the redox regulation is based on studies of innate resistance in Arabidopsis. It proposed that pathogens or elicitors after being recognised by receptors (mostly unknown), activate calcium channel, leading to modulation in cytosolic $\mathrm{Ca}^{2+}$ level and subsequent Nitric Oxide (NO) generation [37]. Subsequently, NO along with the other required redox factors such oxidative burst, could lead to the HR. Oxylipin another by-product of secondary oxidative stress induced by pathogen attack also initiate separate signaling mechanism for cell death.

Three phytohormones, namely SA, Jasmonic Acid (JA) and Ethylene (ET), are known to play significant key roles in a range of different aspects of plant defence mechanism including microbial infection. It is widely established that SA induces defence against biotrophic pathogens, whereas JA activates defence against wounding and necrotrophic pathogens, though there are exceptions as well [38]. It has also been claimed of late that hormone crosstalk associated with plant disease and defence not only means JA-SA antagonism but also a key pathogen virulence approach which modulates hormone signaling, which even includes growth promoters. It is found that the plant growth inhibitors, particularly JA, SA, and ET are primarily involved in plant defence mechanism, whereas Abscisic Acid (ABA), Indole Acetic Acid (IAA), Cytokinins (CK), Brassinosteroids (BR), Gibberellins (GA) and Strigolactones (STR) seems to exert their signaling role in defence, either synergistically or alone. Pathogens have developed strategies either to interfere with or hijack phytohormone pathways to induce resistance or susceptibility. Growth regulators like ET and JA are often placed together in a single signaling network, but these models are probably too simple, since the JA and ET signaling pathways can also modulate each other and other hormones. Furthermore, hemibiotrophic pathogens in different stages of infection can bring on diverse and partly antagonistic signaling involving a host promoters and inhibitors, and make the event more complex [39]. Although our understanding of the mechanisms of pathogen recognition and subsequent host responses to necrotrophs are far from complete, it is broadly accepted that there are major differences in the case of biotrophic and necrotrophic attack. In general, plants recognize pathogens by exploiting different mechanisms. Utilization of specific effectors or non-specific Pathogen Associated Molecular Patterns (PAMPs) or plant $\mathrm{R}$ proteins or Pattern-Recognition Receptors (PRRs) are found to be the mostly used options. As a consequence of these kind of pathogen perception, a cascade of defence reactions including the oxidative burst takes place [40]. Here, the role of specific effectors and corresponding $\mathrm{R}$ proteins are rather to help in plant-biotrophic pathogen interactions [41]. Navarro, et al., (2000) [42], established that the growth-repressing DELLA proteins though induces susceptibility to biotrophic pathogens but impart resistance to necrotrophic pathogens by changing the SA and JA signaling pathways. ROS and oxidative burst can induce the accumulation of three different stress hormones, namely SA, JA and ET. These three stress hormones, which are involved in redox-regulated pathogen signaling, mutually exhibit antagonistic interactions [43].

After the incidence of pathogen infection, several enzymes like NADPH oxidase (Rboh), peroxidases, SOD, oxalates oxidases (OA), LOX, quinine reductase-b (QRb) and Amine

Citation: Dey N, Roy UK, Aditya M, Bhattacharjee S (2020) Defensive strategies of ROS in Programmed Cell Death associated with hypertensive response in plant pathogenesis. Ann Syst Biol 3(1): 001-009. DOI: https://dx.doi.org/10.17352/asb.000004 


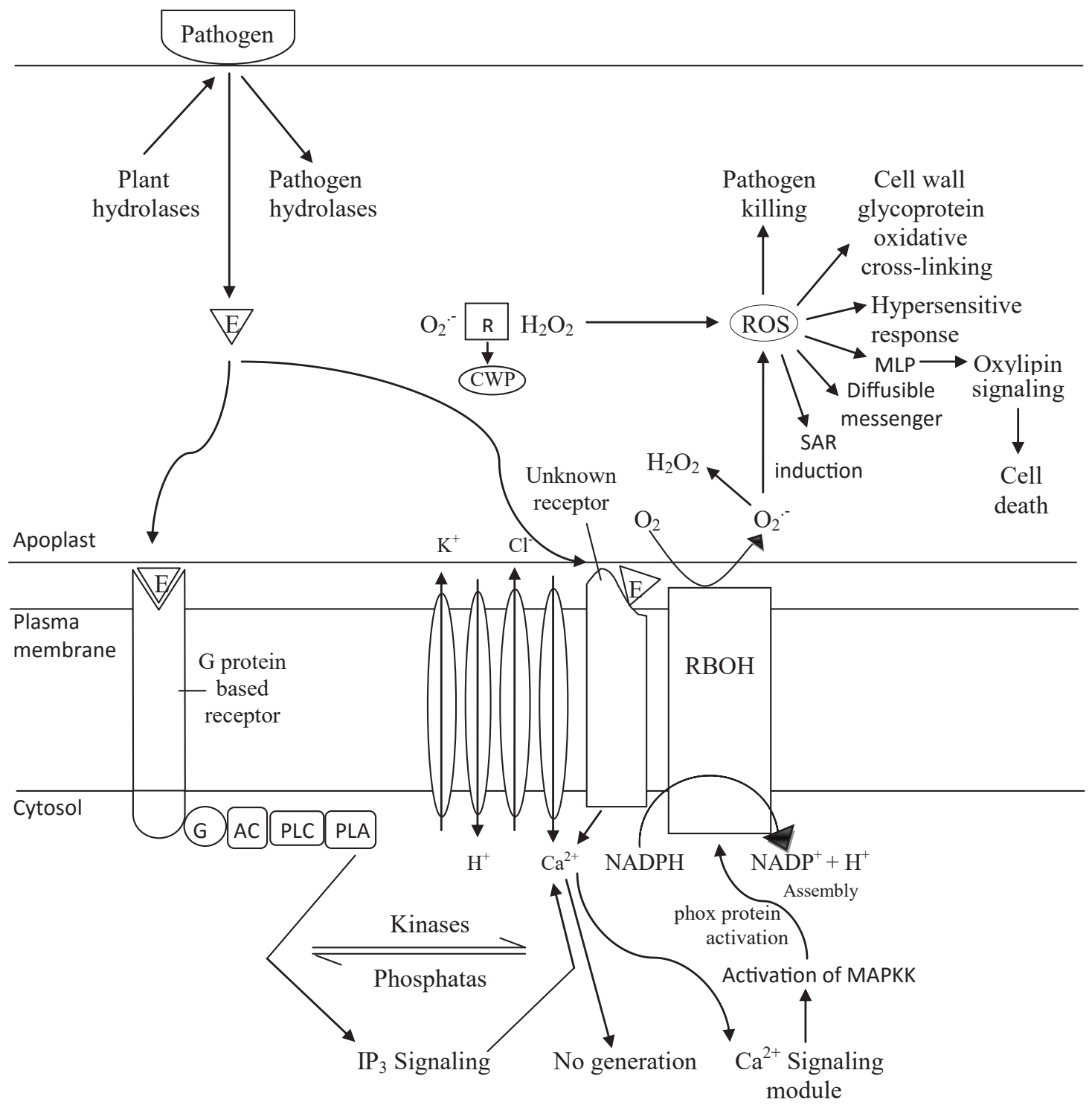

Figure 1: Origin and consequences of ROS signaling during plant - pathogen interaction (Detail in text).

Oxidases (AO) [4], are in general up-regulated and contribute in the genesis of oxidative burst and subsequent redox signaling. In non-infected plant tissues antioxidants are able to counterbalance the damaging effects of ROS. However, if severe infection occurs and the antioxidants fail to scavenge the over-produced ROS, cell death and necrosis takes place. Consequently, elevation of antioxidant potential of plants should enhance their tolerance to the development of necrosis caused by pathogens [9].

\section{ROS and Hypersensitive Response (HR)}

The HR put a ceiling on the growth of the pathogen and is highly competent against biotrophic pathogens, since, with the sacrifice of host cells, the nutrient delivery is removed [44]. Apart from that, higher level ROS and phytoalexins produced in these cells apparently assist to kill the pathogens [45]. Under unfavourable environmental conditions including infection, ROS may originate primarily from cell surface, chloroplasts, mitochondria and peroxisomes [46]. The HR is often not efficient against necrotrophic pathogens since these usually kill host cells to feed on them [47]. Therefore, for true necrotrophic pathogens, such as Botryotinia fuckeliana, it has been suggested that plant cell death is beneficial for infection, leading to improved colonisation [44]. On the contrary, there is a group of pathogens, often considered to be biotrophic, which are in fact inhibited to some extent by HR, e.g., Pyrenophorateres and Magnaporthegrisea $[48,49]$. In fact, the formation of ROS is the first response detected within minutes of an attack by virulent or avirulent pathogen [50]. This extremely fast and transient ROS generation may be due to a biologically nonspecific reaction. After some time, a second, massive and prolonged ROS production, called oxidative burst, occurs in cells attacked by avirulent pathogens. This biphasic kinetics of ROS production and oxidative burst is typical for incompatible plant-pathogen interactions that are characterized by HR [1]. Apoplastic SOD isoenzymes are then accountable for the 
formation of $\mathrm{H}_{2} \mathrm{O}_{2}$ by means of dismutation of $\mathrm{O}_{2}-{ }^{-}$. Confirmation for other sources of ROS has also been given, as LOX acting on poly unsaturated fatty acids (PUFAs) derived from membrane lipids during oxidative membrane damage $[51,52]$. Similarly, extra-cellular $\mathrm{H}_{2} \mathrm{O}_{2}$ could be directly generated by means of a host of apoplastic enzymes, like flavin polyamine oxidases, copper amine oxidase, and oxalate oxidase [53]. Enhancement of mechanical barriers slows down pathogen penetration, allowing plant cells to induce defence responses that require more time to be activated in biological membranes. Apart from these, it is also capable of acting as intracellular signal, which is able to activate defence responses of plants [54].

Generation of ROS in the apoplast, mediated by NADPH oxidase (Rboh) activities encoded by the Rboh gene family, has long been considered as a fundamental attribute of the HR. Plants usually contain several Rboh genes (ten in Arabidopsis) which are transcriptionally up-regulated by pathogenic infection, and whose products display a certain degree of functional overlap [55]. Molecular genetics studies with Rboh mutants and antisense lines consolidate the role played by $\mathrm{NADPH}$ oxidase isoforms in the pathogen-induced oxidative burst [55]. Extracellular ROS production has been linked to direct lipid peroxidation, to the alkalinisation of the apoplast, thereby propagating the redox signal by alkali-responsive peroxidases, or to alterations in the levels and/or redox status of antioxidant pools [56]. Interestingly, down regulation or elimination of Rboh genes could lead to variable effects on the HR. For example, although Arabidopsis RbohD and RbohF mutants exhibited lower ROS accumulation, they displayed enhanced HR when introduced into a lsd 1 mutant background, or when challenged with avirulent bacteria [55]. These results indicate that while NADPH oxidase activity is required for pathogen induced ROS production in the apoplast, these ROS might serve different signaling purposes during the HR [55].

At molecular level, ROS-derived signals kick off global changes in gene expression through regulation and modulation in activities of a specific subset of transcription factors. Those changes trigger different genetic programs including PCD [57]. The initial study of $\mathrm{H}_{2} \mathrm{O}_{2}$-induced cell death was based on gene silencing of CAT, which resulted in elevation of endogenous $\mathrm{H}_{2} \mathrm{O}_{2}$ levels and triggering of PCD under PCRC [58,57]. In Arabidopsis $\mathrm{H}_{2} \mathrm{O}_{2}$-induced cell death was profiled with a DNA chip representing 6,000 genes [57]. Using a CAT inhibitor, which allowed not only transcriptional profiling but also screening for mutants compromised in $\mathrm{H}_{2} \mathrm{O}_{2}$-induced cell death also corroborate the role of $\mathrm{H}_{2} \mathrm{O}_{2}$ in the process. Microarray profiling by means of a DNA chips with near-full genome coverage of Arabidopsis resulted in identification of many new $\mathrm{H}_{2} \mathrm{O}_{2}$-responsive genes that are likely to participate in the cell death process. Evaluation of the relevant dataset with the transcriptional analysis during AAL (Alternaria alternate f.sp. lycopersici) toxin-induced cell death exposed a group of genes regulated in an ordinary fashion. A role for the proteasome and the ethylene pathways in the regulation of cell death, within formation supported by functional studies with proteasome and ethylene biosynthesis inhibitors are also proposed. In this regard genes expressing a number of transcription factors as well as other putative or unknown proteins were identified. Transcription factors like the Zat11, WRKY75 which are very strongly up-regulated during senescence [59] are also found to be induced by singlet oxygen and the superoxide radicalgenerating chemical, herbicide paraquat [60].

Elicitor treatment was shown to modulate the endogenous titer of total thiol, GSH and other thiols. Experiments using an artificial precursor for glutathione treatment suggested that an increase in intracellular GSH alone was insufficient to cause phytoalexin accumulation in bean and alfalfa cells [61] The enhanced level of ROS by changing the ratio of GSH/GSSG modulates the expression of genes associated with phytoalexin production. Further, experimental evidences showed that exogenous application of GSH caused up-regulation in transcript abundance of the genes PAL (Phenyl-ammonialyase) and CS (chalcone synthase) in bean cell suspensions [62]. A later study reported that both GSH and GSSG elicit Phenyl ammonia lyase enzyme activity and phytoalexin accumulation [61].

Inhibition of GHS synthesis in carrot induced phytoalexin accumulation [59]. Lipid peroxides generated by nonenzymatic membrane lipid peroxidation (MLP) instigated by ROS may serve as precursors in the synthesis of JA, a known regulator of severa1 defence-related genes that expressed during the HR [63]. This ROS-dependent source of lipid peroxides may augment an enzymatic pathway for the production of JA involving phospholipases and LOX [63]. SA, which is generally believed to be the inducer of specific plant defence genes during the development of Systemic Acquired Resistance (SAR), evoke its action by inhibiting CAT activity [26,64], causing increased $\mathrm{H}_{2} \mathrm{O}_{2}$ concentrations necessary for its role as second messenger.

\section{Pathogen, ROS signaling and PCD}

Perception and sensing of pathogen activates specific MAPK, which in turn can make possible translocation of the signal to the nucleus where it activates transcription factors through phosphorylation, thereby modulating expression of genes [65]. In tobacco, SA-Induced Protein Kinase (SIPK) and Wound-Induced Protein Kinase (WIPK), are regulated by a common upstream MAPK, which is also found to be involved in signaling associated with PCD [66]. Another MAPK, Ntf4 when expressed in transgenic tobacco plants, exhibiting a similar function to SIPK and WIPK, found to up-regulate PCD under treatment with the elicitor cryptogen from Phytophthora cryptogea [67]. These experiments unequivocally indicate signaling role of pathogen elicitor during PCD. The combined activation of SIPK, Ntf 4 and WIPK can also induce an HR-like PCD [68]. Further evidence for a role of pathogen induced ROS in signaling has come from the fact that addition of low doses of ROS or ROS inducers stimulates the induction of detoxification mechanisms, such as SOD and GST, and activation of other defence mechanisms in neighbouring cells [11]. Molecular genetic studies support the existence of positive amplification loops involving NADPH oxidases in ROS signaling [69]. These feedback loops might be activated by low titer of ROS, particularly $\mathrm{H}_{2} \mathrm{O}_{2}$ and result in amplification of the ROS signals.

Citation: Dey N, Roy UK, Aditya M, Bhattacharjee S (2020) Defensive strategies of ROS in Programmed Cell Death associated with hypertensive response in plant pathogenesis. Ann Syst Biol 3(1): 001-009. DOI: https://dx.doi.org/10.17352/asb.000004 
It has been reported that a small GTP-binding protein, Rac, regulates ROS production in rice, most likely through an Rboh, and induces cell death in rice cells [70]. Togetherly, MAPK and calcium dependent protein kinases seem to play central roles in the regulation of pathogen-responsive Rboh or NADPH oxidases at the transcriptional and post-transcriptional levels, respectively [71]. It has been suggested that the HR is triggered only by balanced production of the ROS, $\mathrm{H}_{2} \mathrm{O}_{2}$ [72] Signaling pathways downstream to $\mathrm{H}_{2} \mathrm{O}_{2}$ is yet to be unfolded. Nevertheless, it has been shown that ROS signaling during both PCD and defence responses requires several important second messengers like $\mathrm{Ca}$, Cyclic Adenosine Monophosphate (cAMP) etc. [73].

Growth regulator SA has been shown to be involved in defence responses under biotic stress. SA levels increased significantly in tobacco cells in the periphery of infection sites when infected with Tobacco mosaic virus [74]. SA along with ROS acted synergistically in a signal amplification loop to instigate the HR and the establishment of systemic defences [5]. SA production can also down-regulate those ROS scavenging systems that, in turn, can contribute to ROS burst following pathogen recognition [75]. Further, the activation of a redox-signaling pathway possessing a MAPK module has also been reported in response to infection by avirulent pathogens in Arabidopsis [76].

Molecular genetics study of Arabidopsis or tobacco plants transformed with the bacterial gene encoding for a salicylate hydroxylase exhibited that these plants unable to accumulate SA and are more sensitive to pathogens [77]. The studies on the effects of pathogens or elicitors in these plants, also supplemented with the use of mutants, have allowed researchers to identify the steps of the HR programme that are SA-dependent [54]. These plants, in which, CAT and APX (ascorbate peroxidase) are under-expressed, are hyperresponsive to pathogen attack $[78,52]$. This fact further corroborates the fact that the ability of plant cells to control or regulate the competence of ROS-removal strategies is a vital point in their resistance against pathogens.

\section{ROS signaling and SAR}

A plausible role for local ROS accumulation and redox changes in systemic signaling leading to the instigation of SAR was highlighted in molecular genetics experiment with transgenic tobacco having an antisense CAT gene [28,64] Exposure of these plants to Excess Photochemical Energy (EPE) for two successive days resulted in visible necrotic lesions and induced synthesis of PR proteins in adjacent, light-shielded systemic leaf tissues. In contrast, exposure to EPE for four hours up-regulates the synthesis of PR proteins in adjacent, light-shielded local, but not systemic tissue, in absence of necrosis. Thus the ROS-mediated up-regulation of SAR genes could be uncoupled from cell death in local tissues. However, local ROS-mediated cell death was found to be a prerequisite for the accumulation of PR proteins in systemic tissues. A local oxidative burst in response to an avirulent isolate of $P$. syringae tomato-induced "microbursts" of ROS formation in systemic leaf tissue was found. These microbursts drove the formation of "micro- HRs," which subsequently preceded the establishment of SAR. Co-infiltration of the Rboh or NADPH oxidase inhibitor, DPI, with avirulent $P$. syringae tomato ameliorated engagement of a local oxidative burst and blocked the formation of systemic microbursts and the development of SAR. In the corresponding gain-of-function experiment local infiltration of an $\mathrm{H}_{2} \mathrm{O}_{2}$ generating system induced systemic microbursts and subsequently SAR. Hence, an ROS mediated systemic signaling network may also found to mediate the establishment of plant resistance to infection. Pathogen induced changes in redox status or ROS accumulation may, therefore, integrate a excess of local and systemic defence reaction.

\section{Conclusion and Perspective}

The oxidative burst or rapid production of ROS in host plant cell in response to pathogenic invasion has immense physiological significance and not a consequence of plantpathogen interaction. It helps the host plant ultimately to establish different strategies of defensive barriers against pathogens. The roles of other factors such as plant growth regulators, environmental cues and activation of different interactive signaling pathways play an important role for not only the accumulation of ROS but also its subsequent physiology. Different types of pathogens and elicitors with varying ability to trigger ROS production might be possible reasons for conflicting results. Therefore, pathogen infections persuade fast accumulation of ROS which are involved in limiting pathogenic entrance, induction of signal transduction of many defence responses or PCD.

\section{References}

1. Lamb C, Dixon RA (1997) The oxidative burst in plant disease resistance. Annual Review of Plant Physiology and Plant Molecular Biology. 48: 251-275. Link: http://bit.ly/2w6dAff

2. Mittler R, Vanderauwera SN, Suzuki G, Miller V, Tognetti K, et al. (2011) ROS signaling: the new wave? Trends Plant Sci 16: 300-309. Link: http://bit.ly/33ex39T

3. Scheel D (1998) Resistance response physiology and signal transduction. Cur Opin Plant Biol 1: 305-310. Link: http://bit.ly/38IV5L7

4. Shetty NP, Lyngs HJJ, Jensen D, Collinge DB, Shekar HC (2008) Roles of reactive oxygen species in interactions between plants and pathogens. Eur Plant Pathol 121: 267-280. Link: http://bit.ly/2xsyju3

5. Torres MA, Jones JDG, Dangl JL (2006) Reactive oxygen species signaling in response to pathogens. Plant Physiol 141: 373-378. Link: http://bit.ly/38PoX8E

6. Asai S, Yoshioka H (2009) Nitric oxide as a partner of reactive oxygen species participates in disease resistance to necrotrophic pathogen Botrytis cinerea in Nicotiana benthamiana. Mol Plant-Microbe Interact 22: 619-629. Link: http://bit.ly/2TMqGat

7. Torres MA (2010) ROS in biotic interactions. Physiologia Plantarum 138: 414429. Link: http://bit.ly/2wYkgMv

8. Choi HW, Kim YJ, Lee SC, Hong JK, Hwang BK (2007) Hydrogen peroxide generation by the pepper extracellular peroxidase $\mathrm{CaPO}_{2}$ activates local and systemic cell death and defence response to bacterial pathogens. Plant Physiology 145: 890-904. Link: http://bit.ly/2WcpE9w

9. Barna B, Adam A, Kiraly Z (1993) Juvenility and resistance of a superoxidetolerant plant to disease and other stresses. Natur-wissenshaften 80: 420422. Link: http://bit.ly/38TG6yk 
10. Doke N, Miura Y, Sanchez LM, Park HJ, Noritake T, et al. (1996) The oxidative burst protects plants against pathogen attack: Mechanism and role as an emergency signal for plant bio-defence-A review. Gene 179: 45-51. Link: http://bit.ly/2w6eNTP

11. Levine A, Tenhaken R, Dixon $\mathrm{R}$, Lamb C (1994) $\mathrm{H}_{2} \mathrm{O}_{2}$ from the oxidative burst orchestrates the plant hypersensitive disease resistance response. Cell 79 583-593. Link: http://bit.ly/2W6ZR2x

12. Bi YM, Kenton P, Mur L, Darby R, Draper J (1995) Hydrogen peroxide does not function downstream of salicylic acid in the induction of PR protein expression. Plant J 8: 235-245. Link: http://bit.ly/3aQAPIV

13. Baker CJ, Orlandi EW, Mock NM (1993) Harpin, an elicitor of the hypersensitive response in tobacco caused by Erwinia amylovora, elicits active oxygen production in suspension cells. Plant Physiol 102: 1341-1344. Link: http://bit.ly/33eyC7L

14. Yamasaki H, Sakihama Y, Ikehara N (1997) Flavonoid-peroxidase reaction as detoxification mechanism of plant cells against $\mathrm{H}_{2} \mathrm{O}_{2}$. Plant Physiol 115: 14051412. Link: http://bit.ly/3cXXdlt

15. Kawano T, Muto S (2000) Mechanism of peroxidase actions for salicylic acid-induced generation of active oxygen species and an increase in cytosolic calcium in tobacco suspension culture. J Exp Bot 51: 685-693. Link: http://bit.ly/2T03xon

16. Raz V, Fluhr R (1992) Calcium requirement for ethylene dependent responses. Plant Cell 4: 1123-1130. Link: http://bit.ly/2T01Hny

17. Chen CS, Chao HT, Pan RL, Wei YH (1997) Hydroxyl radical-induced decline in motility and increase in lipid peroxidation and DNA modification in human sperm. Biochem Mol Biol Int 43: 291-303. Link: http://bit.ly/2QeKOQx

18. Ivenish G, Valeina A, Ozol D (1995) Induction of ascorbate peroxidase-activity in stressed pine (Pinus sylvestris L.) needles-A putative role for ethylene. Plant Sci 112: 167-173. Link: http://bit.ly/2w7kctZ

19. Degousie H, Triantaphilides C, Montillet JL (1994) Involvement of oxidative process in the signaling mechanism leading to the activation of glyceollin synthesis in soyabean (Glycine haase). Plant Physiol 104: 945-952. Link: http://bit.ly/33fOLcY

20. Kiba A, Toyota K, Ichinose Y, Yamada T, Shiraishi T (1996) Species-specific suppression of superoxide-anion generation of surfaces of pea leaves by the suppressor from Mycosphaerella pinodes. Ann Phyto pathol Soc Jpn 62: 508 512. Link: http://bit.ly/390oPaP

21. Bowell GP, Butt VS, Davies DR, Zimmerlin A (1995) The origin of the oxidative burst in plants. Free Radical Res 23: 517-532. Link: http://bit.ly/390IkAe

22. Larkindale J, Knight MR (2002) Protection against heat stress induced oxidative damage in Arabidopsis involves calcium, abscisic acid, ethylene, and salicylic acid. Plant Physiol 128: 682-695. Link: http://bit.ly/39Ui1c0

23. Yoshioka H, Sugie K, Park HJ, Maeda H, Tsuda N, et al. (2001) Induction of plant gp91 phox homolog by fungal cell wall, arachidonic acid, and salicylic acid in potato. Mol Plant-Microbe Interact 14: 725-736. Link: http://bit.ly/33qCqTD

24. Van Aken O, Van Breusegem F (2015) Licensed to Kill: Mitochondria, Chloroplasts, and Cell Death. Trends Plant Sci 20: 754-766. Link: http://bit.ly/2Q9PqqX

25. Desikan R, Burnett EC, Hancock JT, Neill SJ (1998) Harpin and hydrogen peroxide induce the expression of a homologue of gp91-phox in Arabidopsis thaliana suspension cultures. J Exp Bot 49: 1767-1771. Link: http://bit.ly/3cU5kzC

26. Chen Z, Silva H, Klessig DF (1993) Active oxygen speaes in the induction of plant systemic acquired resistance by salicylic acid. Science 262: 1883-1886. Link: http://bit.ly/39SxPMc

27. López-Delgado H, Dat JF, Foyer CH, Scott IM (1998) Induction of thermotolerance in potato microplants by acetylsalicylic acid and $\mathrm{H}_{2} \mathrm{O}_{2}$. Journal of Experimental Botany 49: 713-720. Link: http://bit.ly/33hfZA3
28. Wu Y, Kuzma J, Marechal E, Graeff R, Lee HC, et al. (1997) Abscisic Acid Signaling Through Cyclic ADP-ribose in Plant. Science 278: 2126-2130. Link: Link: http://bit.ly/2IIdP2V

29. Chamnongpol S, Willekens H, Moeder W, Langebartels C, Sandermann H, et al. (1998) Defense activation and enhanced pathogen tolerance induced by $\mathrm{H}_{2} \mathrm{O}_{2}$ in transgenic tobacco. Proc Natl Acad Sci, USA 95: 5818-5823. Link: http://bit.ly/3d1sh4b

30. Alvarez ME, Pennell RI, Meijer PJ, Ishikawa A, Dixon RA, et al. (1998) Reactive oxygen intermediates mediate a systemic signal network in the establishment of plant immunity. Cell 92: 773-784. Link: http://bit.ly/2vfCEA2

31. Jabs T, Dietrich RA, Dangl JL (1996) Initiation of runaway cell death in an Arabidopsis mutant by extracellular superoxide. Science 273: 1853-1856. Link: http://bit.ly/2vV64Ed

32. Jabs T (1999) Reactive oxygen intermediates as mediators of programmed cell death in plants and animals. Biochem Pharmacol 57: 231-245. Link: http://bit.ly/33fykgH

33. Wisniewski JP, Cornille P, Agnel JP, Montillet JL (1999) The extension multigene family responds differentially to superoxide or hydrogen peroxide in tomato cell cultures. FEBS Lett 447: 264-268. Link: http://bit.ly/3cVwy95

34. McDowell JM, Dangl JL (2000) Signal transduction in the plant immune response. Trends Biochem Sci 25: 79-82. Link: http://bit.ly/2TMbf22

35. Pei ZM, Murata Y, Benning G, Thomine S, Klüsener B, et al. (2000) Calcium channels activated by hydrogen peroxide mediate abscisic acid signaling in guard cells. Nature 406: 731-734. Link: http://bit.ly/38K1vK1

36. Blumwald E, Aharon GS, Lam BCH (1998) Early signal transduction pathways in plant-pathogen interactions. Trends in Plant Science 3: 342-346. Link: http://bit.ly/2w6gUHf

37. Ali R, Ma W, Lemtiri Chlieh F, Tsaltas D, Leng Q, et al. (2007) Death don't have no mercy and neither does calcium: Arabidopsis Cyclic Nucleotide Gated Channel2 and innate immunity. The Plant Cell 19: 1081-1095. Link: http://bit.ly/39PxXMz

38. Smith JL, De Moraes CM, Mescher MC (2009) Jasmonate and Salycylate mediated plant defense responses to insect hebivores, pathogens and parasitic plants. Pest Management Science 65: 497-503. Link: http://bit.ly/3aQhuaW

39. Oliver RP, Ipcho SVS (2004) Arabidopsis pathology breathes new life into the necrotrophs-vs.-biotrophs classification of fungal pathogens. Molecular Plant Pathology 4: 347-352. Link: http://bit.ly/3cVGwHo

40. Jones JDG, Dangl JL (2006) The plant immune system. Nature 444: 323-329. Link: https://go.nature.com/2vk5Shp

41. Ciuffetti LM, Manning VA, Pandelova I, Betts MF, Martinez JP (2010) HostSelective Toxins, PtrToxA and PtrToxB as Necrotrophic Effectors in the Pyrenophora Tritici-Repentis-Wheat Interaction. New Phytol 187: 911-919. Link: http://bit.ly/2U9IBs6

42. Navarro L, Bari R, Achard P, Lison P, Nemri A, et al. (2000) DELLAs control plan immune responses by modulating the balance of jasmonic acid and salicylic acid signaling. Current Biology 18: 650-655. Link: http://bit.ly/3cUWSjJ

43. Kangasjarvi J, Jaspers $P$, Kollist $H$ (2005) Signaling and cell death in ozone exposed plants. Plant Cell Environment 28: 1021-1036. Link: https://bit.ly/2U6CSSw

44. Greenberg JT, Yao N (2004) The role and regulation of programmed cell death in plant-pathogen interactions. Cell Microbiol 6: 201-211. Link: https://bit.ly/2QjevA9

45. Li J, Zhang ZG, Ji R, Wang YC, Zheng XB (2006) Hydrogen peroxide regulates elicitor PB90-induced cell death and defense in non-heading Chinese cabbage. Physiol Mol Plant Pathol 67: 220-230. Link: https://bit.ly/2QkSqkx

Citation: Dey N, Roy UK, Aditya M, Bhattacharjee S (2020) Defensive strategies of ROS in Programmed Cell Death associated with hypertensive response in plant pathogenesis. Ann Syst Biol 3(1): 001-009. DOI: https://dx.doi.org/10.17352/asb.000004 
46. Amirsadeghi S, Robson CA, Vanlerberghe GC (2007) The role of the mitochondrion in plant responses to biotic stress. Physiol Plant 129: 253-266. Link: https://bit.ly/3aU6HMM

47. Govrin E, Levine A (2000) The hypersensitive response facilitates plant infection by the necrotrophic pathogen Botrytis cinerea. Curr Biol 10: 751-757. Link: https://bit.ly/2wUD7rX

48. Iwai T, Seo S, Mitsuhara I, Ohashi Y (2007) Probenazole-induced accumulation of salicylic acid confers resistance to Magnaporthe grisea in adult rice plants. Plant Cell Physiol 48: 915-924. Link: https://bit.ly/2WeM89N

49. Jorgensen HJL, de Neergaard E, Smedegaard-Petersen V (1993) Histological examination of the interaction between Rhynchosporium secalis and susceptible and resistant cultivars of barley. Physiol Mol Plant Pathol 42: 345 358. Link: https://bit.ly/2QgZj6m

50. Adam A, Farkas T, Somlayai G, Hevesi M, Kiraly Z (1989) Consequence of $\mathrm{O}_{2}$ generation during bacterially induced hypersensitive reaction in tobacco: deterioration of membrane lipids. Physiol Mol Plant Pathol 34: 13-26. Link: https://bit.ly/2QirS3o

51. Croft KPC, Voisey CR, Slusarenko AJ (1990) Mechanisms of hypersensitive cell collapse: correlation of increased lipoxygenase activity with membrane damage in leaves of Phaseolus vulgaris $L$. inoculated with an avirulent race of Pseudomonas syringae pv. phaseolicola. Physiol Mol Plant Pathol 36: 49-62. Link: https://bit.ly/3aU7bT6

52. Mittler R (2017) ROS Are Good. Trends in Plant Sci 22: 11-19. Link: https://bit.ly/2w9u6v7

53. Rea G, Laurenzi E, Tranquilli R, D'Ovidio R, Federico R, et al. (1998) Development ally and wound-regulated expression of the gene encoding a cell wall copper amine oxidase in chickpea seedlings. FEBS Lett 437: 177-182. Link: https://bit.ly/2wVibRM

54. Durner J, Shah J, Klessig DF (1997) Salicylic acid and disease in plants. Trends Plant Sci 2: 266-274. Link: https://bit.ly/2QkYdXr

55. Torres MA, Dangl JL (2005) Functions of the respiratory burst oxidase in biotic interactions, abiotic stress and development. Curr Opin Plant Biol 8: 397-403. Link: https://bit.ly/38W9TWS

56. Mur LA, Kenton P, Lloyd AJ, Ougham H, Prats E (2008) The hypersensitive response; the centenary is upon us but how much do we know? J Exp Bot 59 : 501-520. Link: https://bit.ly/2UfoZlg

57. Awwad F, Bertrand G, Grandbois M, Beaudoin N (2019) Reactive Oxygen Species Alleviate Cell Death Induced by Thaxtomin A in Arabidopsis thaliana Cell Cultures. Plants 8: 332. Link: https://bit.ly/2xHdTOe

58. Vandenabeele S, Van Der Kelen K, Dat J, Gadjev I, Boonefaes T, et al. (2003) A comprehensive analysis of hydrogen peroxide-induced gene expression in tobacco. Proc Natl Acad Sci USA 100: 16113-16118. Link: https://bit.ly/2INLZCp

59. Guo ZJ, Nakagawara S, Sumitani K, Ohta Y (1993) Effect of intracellula glutathione level on the production of 6-methoxymellein I in cultured carro (Daucus carota) cells. Plant Physiol 45-51. Link: https://bit.ly/2TSyAzn

60. Op den Camp RGL, Przbyla D, Ochsenbein C, Laloi C, Kim C, et al. (2003) Rapid induction of distinct stress responses after the release of singlet oxygen in Arabidopsis. Plant Cell 15: 2320-2332. Link: https://bit.ly/2TUhgty

61. Edwards R, Blount JW, Dixon RA (1991) Glutathione and elicitation of the phytoalexin response in legume cell cultures. Planta 184: 403-409. Link: https://bit.ly/39TJWIJ

62. Wingatei VPM, Lawton MA, Lamb CJ (1988) Glutathione causes a massive and selective induction of plant defense genes. Plant Physiol 87: 206-210. Link: https://bit.ly/3aVk90L
63. Farmer EE, Ryan CA (1992) Octadecanoid precursors of jasmonic acid activate the synthesis of wound-inducible proteinase inhibitors. Plant Cell 4: 129-134. Link: https://bit.ly/2xHRU9R

64. Zhou F, Menke FLH, Yoshioka K, Moder W, Shirano Y, et al. (2004) High humidity suppresses ssi4-mediated cell death and disease resistance upstream of MAP kinase activation, $\mathrm{H}_{2} \mathrm{O}_{2}$ production and defense gene expression. Plant $J$ 39: 920-932. Link: https://bit.ly/2wcmCY9

65. Zhang S, Liu Y, Klessig DF (2000) Multiple levels of tobacco WIPK activation during the induction of cell death by fungal elicitins. Plant J 23: 339-347. Link: https://bit.ly/2ILM3Tj

66. Czarnocka W, Karpiński S (2018) Friend or foe? Reactive oxygen species production, scavenging and signaling in plant response to environmenta stresses. Free Radic Biol Med 122: 4-20. Link: https://bit.ly/39X3tlk

67. Ren D, Yang KY, Li GJ, Liu Y, Zhang S (2006) Activation of Ntf4, a tobacco mitogen-activated protein kinase, during plant defense response and its involvement in hypersensitive response-like cell death. Plant Physiol 141: 1482-1493. Link: https://bit.ly/2Wks1qP

68. Liu G, Greenshields DL, Sammynaiken R, Hirji RN, Selvaraj G, et al. (2007) Targeted alterations in iron homeostasis underlie plant defense responses. $J$ Cell Sci 120: 596-605. Link: https://bit.ly/3aVUEyE

69. Dat JF, Pellinen R, Beeckman T, Van de Cotte B, Langebartels C, et al. (2003) Changes in hydrogen peroxide homeostasis trigger an active cell death process in tobacco. Plant J 33: 621-632. Link: https://bit.ly/33sEydu

70. Kawasaki T, Henmi K, Ono E, Hatakeyama S, Iwano M, et al. (1999) The smal GTP-binding protein Rac is a regulator of cell death in plants. Proc Natl Acad Sci U S A 96: 10922-10926. Link: https://bit.ly/3d30fmQ

71. Kobayashi M, Ohura I, Kawakita K, Yokota N, Fujiwara M, et al. (2007) Calcium-dependent protein kinases regulate the production of reactive oxygen species by potato NADPH oxidase. Plant Cell 19: 1065-1080. Link: https://bit.ly/2vnnhph

72. Delledonne M, Murgia I, Ederle D, Sbicego PF, Biondani A, et al. (2002) Reactive oxygen intermediates modulate nitric oxide signaling in the plant hypersensitive disease-resistance response. Plant Physiol Biochem 40: 605610. Link: https://bit.ly/38UYPJw

73. Van Breusegem F, Dat JF (2006) Reactive oxygen speciesin plant cell death Plant Physiol 141: 384-390. Link: https://bit.ly/3b0T3Ye

74. Enyedi AJ, Yalpani N, Silverman P, Raskin I (1992) Localization, conjugation and function of salicylic acid in tobacco during the hypersensitive reaction to tobacco mosaic virus. Proc Natl Acad Sci U S A 89: 2480-2484. Link: https://bit.ly/3d5WEXc

75. Klessig DF, Durner J, Noad R, Navarre DA, Wendehenne D, et al. (2000) Nitric oxide and salicylic acid signaling in plant defense. Proceedings of the National Academy of Sciences of the United States of America 97: 8849-8855. Link: https://bit.ly/3dcbsUa

76. Suzuki K (2002) Map kinase cascade in elicitor signal transduction. J Plant Res 115: 237-244. Link: https://bit.ly/2vYAFkd

77. Hammond-Kosack KE, Jones JDG (1996) Resistance gene-dependent plant defense responses. Plant Cell 8: 1773-1791. Link: https://bit.ly/2IRd8nS

78. Mittler R, Herr EH, Orvar BL, Van Camp W, Willekens H, et al. (1999) Transgenic tobacco plants with reduced capability to detoxify reactive oxygen species intermediates are hyperresponsive to pathogen infection. Proc Natl Acad Sci USA 96: 14165-14170. Link: https://bit.ly/3b1Ud6a

Copyright: @ 2020 Dey N, et al. This is an open-access article distributed under the terms of the Creative Commons Attribution License, which permits unrestricted use distribution, and reproduction in any medium, provided the original author and source are credited.

Citation: Dey N, Roy UK, Aditya M, Bhattacharjee S (2020) Defensive strategies of ROS in Programmed Cell Death associated with hypertensive response in plant pathogenesis. Ann Syst Biol 3(1): 001-009. DOl: https://dx.doi.org/10.17352/asb.000004 